\title{
Assessment Approach of Melicertus kerathurus Stock along the North-Eastern Tunisian Coast Using a Surplus Production Model Incorporating Temperature Parameter
}

\author{
Héla Jaziri, Widien Khoufi, Sadok Ben Meriem \\ National Institute of Sciences and Technologies of the Sea (INSTM), Port La Goulette, Tunisia \\ Email: jaziri.hela@yahoo.fr
}

Received 5 September 2015; accepted 1 December 2015; published 4 December 2015

Copyright (C) 2015 by authors and Scientific Research Publishing Inc.

This work is licensed under the Creative Commons Attribution International License (CC BY). http://creativecommons.org/licenses/by/4.0/

(c) (i) Open Access

\begin{abstract}
In frame of fisheries management, a stock assessment using surplus production models incorporating environmental parameters was dealt with one of the most important commercially crustacean fisheries resources along the Tunisian coast, the Melicertus kerathurus stock. The analysis was carried out for a period of 17 years with a database including fishing efforts, catches, catch per unit effort (CPUE) and sea surface temperature (SST). CLIMPROD is the software used to select the appropriate model and fit to the fishery and environmental data. Overall, SST was positively correlated to the yield and abundance index (CPUE) explaining $47 \%$ and $57 \%$ of their variability respectively, nevertheless. The incorporation of the SST in global model demonstrated that the SST influenced both the catchability and the abundance of this species separately. In fact the impact of SST leads to consider a production model impacted on the one hand by a linear relationship between the CPUE and the fishing effort, and on the other hand by also a linear relationship between the CPUE and the SST for both catchability or abundance of the species. The interpretation of global model with environmental parameters is changed with the incorporation of climate parameter.
\end{abstract}

\section{Keywords}

Melicertus kerathurus, SST, Abundance, Catchability, Assessment 


\section{Introduction}

The last studies of stock assessment are based on age structured models but this type of a single-species stock assessment cannot be easily applied to invertebrates because they are considered as hard-to-age species [1]. For this reason and according to the data available we use surplus production models; however, these models take into consideration only the fishing effort. Knowing that invertebrates are characterized by a short life cycle, so they are often influenced by environmental factors [2]. Therefore, we associated fishing activities and climate parameters to the management of this family.

Among the invertebrates we cited the crustaceans which were the hardest-to-age species compared to cephalopods. This family presents $7 \%$ of the world captures production in marine fishing area and in inland water for 2010. The crustaceans are composed of 7 groups; the shrimp and prawn constitute the most considerable groups presenting $51 \%$ of crustacean's world capture and $4 \%$ of the total world capture [3].

Melicerthus kerathurus (Forskäl, 1775) known as caramote prawn is one of this group. It is a demersal crustacean, widely distributed inhabiting the Mediterranean sea and the eastern Atlantic from the south coast of England to Angola [4] [5] and commercially is among the important species especially in the Mediterranean sea and particularly in Tunisia [6].

Generally, Melicertus kerathurus has not been widely studied [7] even in Tunisia. The first studies began since 1932. The major questions treated were about biology, dynamic, exploitation, fisheries technologies and genetic [8]-[27].

In Tunisia, Melicertus kerathurus is captured along the entire coastline and is a target species by both trawling and artisanal fleet. The south of the country is the most important productive zone during the last 17 years, with a landing reaching up to $95 \%$; among which $65 \%$ are from the trawl and $35 \%$ are from the artisan gear. However the north and the east parts of the country represent a landing of $5 \%$, where $66 \%$ are from the artisan gear.

Its economic contribution to the fishery sector is high because this species is one of these oriented to the exportation. The fiecono in the south is managed through a regulation based on two closed fishing seasons. The first is during the summer (from 10 May to 15 July) and the second is during the autumn (from 15 October to 15 November).

For this study, we exclude the south area and we focus on the north and the east area for a subsequent management of this species.

The object of this paper is presenting the utility of the effect of environmental parameters in stock assessment and as basic information for future fishery management and fishing forecast for Melicertus kerathurus caught in the north and the east of Tunisia, knowing that Melicertus kerathurus fishery is not controlled in this area.

\section{Material and Method}

\subsection{Study Area}

In the Mediterranean Sea, Melicertus kerathurus is collected along the coast especially in the three countries namely, Tunisia, Italy and Greece. We focus our interest in Tunisia. The study area is located from the north to the east of this region covering in the total 9 administrative regions (Figure 1).

\subsection{Data Collected}

Three databases were collected; the first was from FAO through FishStat

(http://www.fao.org/fishery/species/2587/en). Data collected were yearly landing of Melicertus kerathurus of the important countries catching this species operating in the Mediterranean Sea and the Atlantic Ocean. The second database was collected from General Direction of Fishing and Aquaculture (DGPA) in Tunisia. Data were collected from commercial trawl and artisanal vessel operating in the north and the east of Tunisian coast. The fishery statistics have been collected since January 1995 to December 2011. Data used are monthly Melicertus kerathurus landing and fishing effort for the nine administrative regions covering the north and the east of Tunisia (Figure 1). Effort was estimated separately for the industrial trawl and artisanal fisheries, and standardized in kg per trip of artisanal boats. The third database is climatic data, the parameter used is the sea surface temperature $\left(\mathrm{SST}^{\circ} \mathrm{C}\right)$. This type of data was downloading from National Oceanic and Atmospheric Administration (NOAA) through this site: ftp://ftp.emc.ncep.noaa.gov/cmb/sst/oimonth_v2/. The NOAA OI.v2 SST monthly fields are derived by a linear interpolation of the weekly optimum interpolation (OI) version 2 fields to 

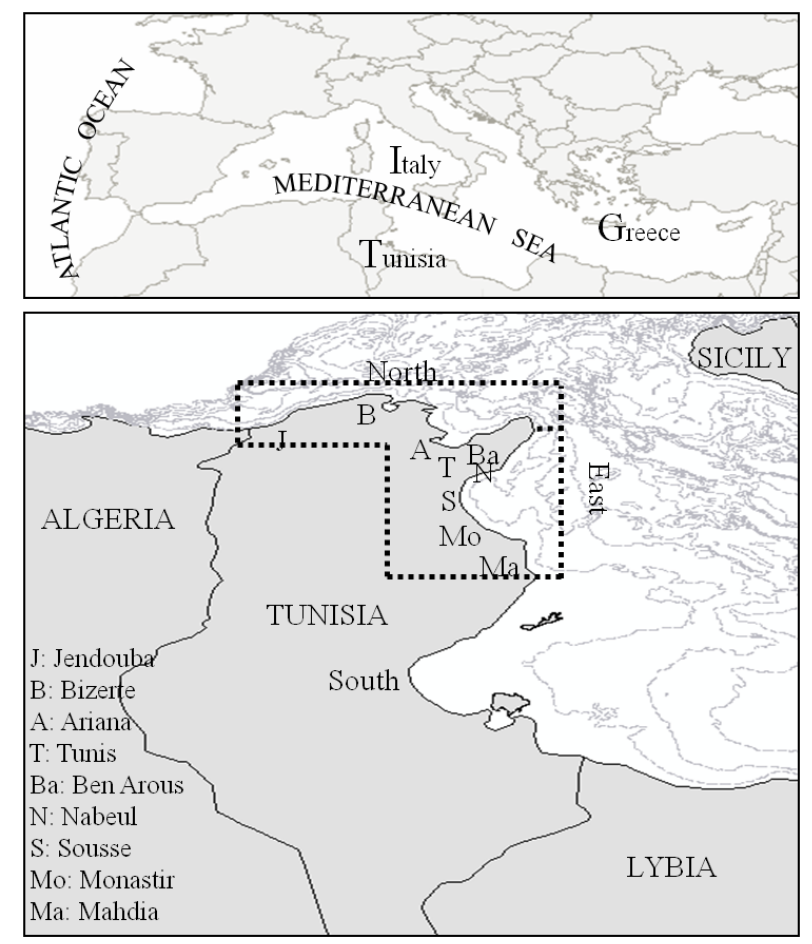

Figure 1. Study area.

daily fields then averaging the daily values over a month. The monthly fields are in the same format and spatial resolution as the weekly fields. The OI sea surface temperature (SST) analysis is produced weekly on a onedegree grid [28].

SST is averaged on a seasonal and yearly time scale. Two seasons are defined as hot covering the spring and the summer and the cold covering the autumn and the winter. In the total, fishery and climatic data were available for 17 year, from 1995 to 2011.

\subsection{Statistical Analysis}

The determination coefficient $\mathrm{R}^{2}$ was carried out to explain the variation of Melicertus kerathurus catches. In order to investigate the consistence patterns for each variable, a cross correlation was used to study the monthly lagged correlation between the landing and the SST using STATISTICA as software. To evaluate the yearly relationship between variables, a correlation coefficient was carried out between landing, effort, CPUE and SST during hot and cold season.

The global models or surplus production models were adopted for stock assessment of Melicertus kerathurus without and including environmental variables using CLIMPROD as software [29].

The fit assessment is mainly based on a Jacknife test which is a resampling technique [30] for the estimation of the parameters and $\mathrm{R}^{2}$ of the models.

For the simple stock assessment, the models were tested and fitted to the data obtained using the most common surplus production models: Schaefer's linear production model [31] [32], the Fox's exponential model [33] and the generalized production model [34]. Nevertheless, the introduction of environmental variable in global model helped us to test 20 equations derived from linear, exponential or quadratic, or a combination of those according to its possible influence on abundance, catchability, or both [29].

\section{Results}

\subsection{Actual Situation of Melicertus kerathurus Production in the Mediterranean Sea and Tunisia}

In the Mediterranean Sea, Melicertus kerathurus is caught along the country riparian the basin, the most impor- 
tant landing are coming firstly from Tunisia, second from Greece and thirdly from Italy. During the last 6 decades, Tunisia was always the first country fishing Melicertus kerathurus with a mean percentage of $40 \%$ from 1950 to 1980, to increase roughly reaching 83\% in 1983 during 3 years. In contrary, to the years after, the landing is varying from a year to year. The moving average for Tunisian production, presenting 2 domes, the first one is small and covering 13 years from 1982 to 1994 nevertheless, the second one is more important and covering the period of 17 years from 1995 to 2011 (Figure 2).

For this paper we focus only on the second dome corresponding to the period from 1995 to 2011. For this period, the Melicertus kerathurus landing are caught along the Tunisian coast from the north, passing by the east to reach the south, where, $95 \%$ of the production is fished and the rest is from the north-east of the country (Figure 3). In the south, the production of this species presented a fluctuation with a decrease reaching the half of the south production. Although, production caught from the north-east area presented an increase reaching the double.

In the south zone, Melicertus kerathurus fished by the industrial engine is the main exploitation method

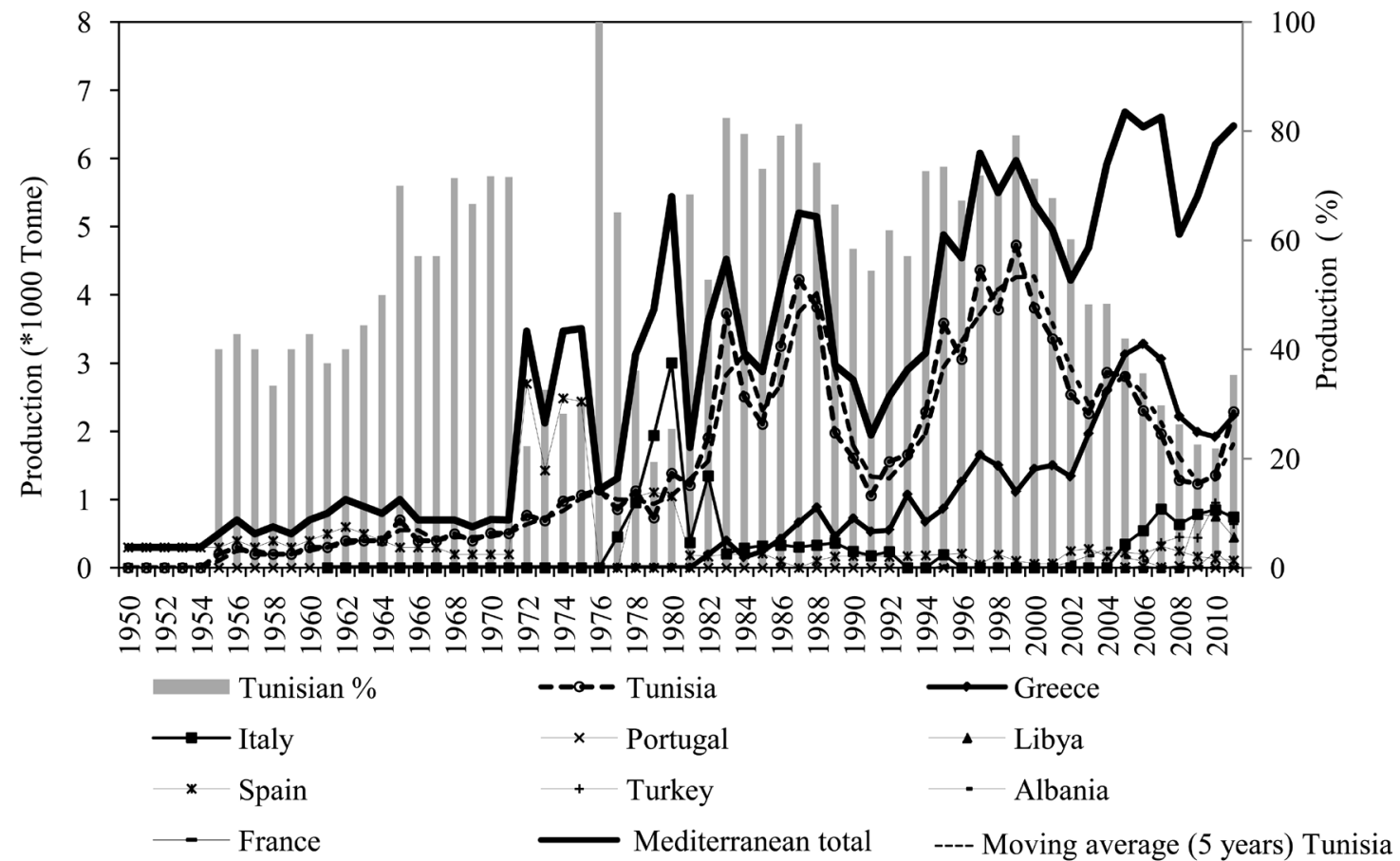

Figure 2. Melicertus kerathurus landing in the countries riparian the mediterranean sea.

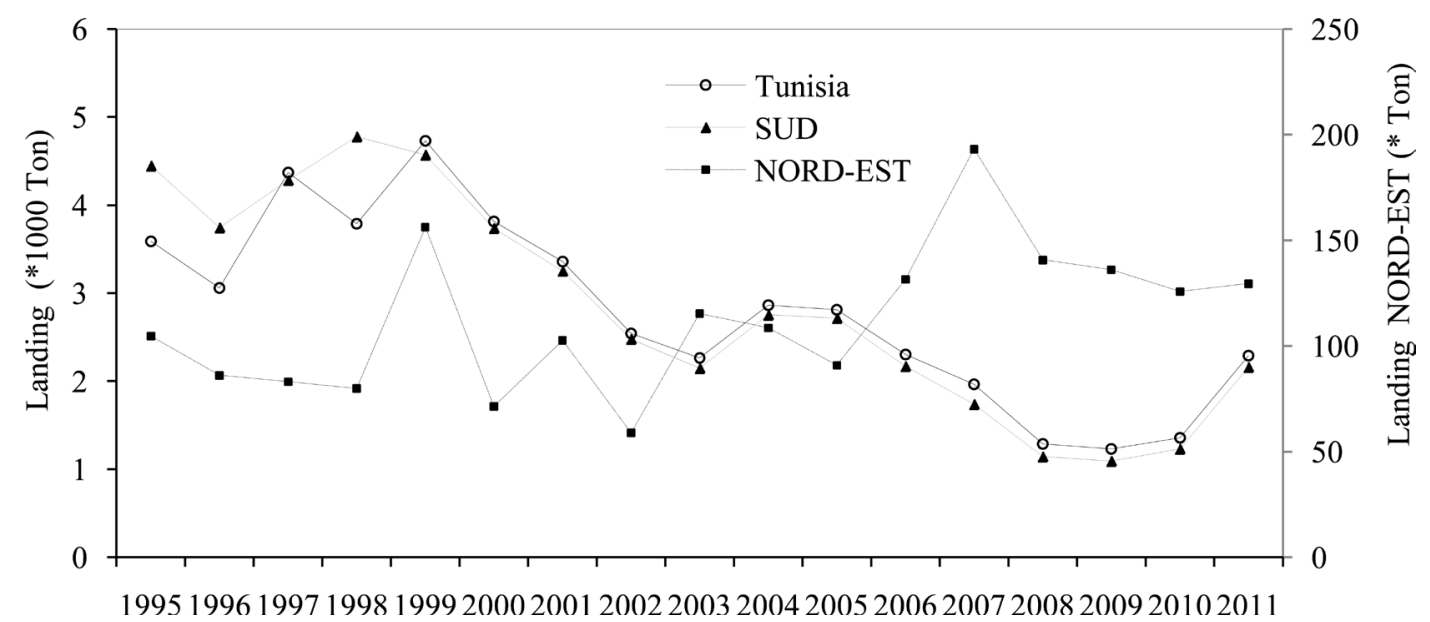

Figure 3. Melicertus kerathurus landings along the tunisian coast. 
compared to the artisanal, which is the most important one for the north-east of Tunisia (Figure 4).

\subsection{Assessment of Melicertus kerathurus Stock off the North-East of Tunisia Using Classical Approach of Surplus Production Models}

According to CLIMPROD results and basing on the test of Jacknife, the linear production model and the exponential production model, usually named "Schaefer model" and "Fox model" respectively, were chosen to evaluate the stock situation for Melicertus kerathurus during the last 17 years (Table 1). For this case, coefficient of determination $\mathrm{R}^{2}$ explain just 45 (Schaefer model) and $43 \%$ (Fox model) of the variation of the production by the fishing effort and the rest is due to the white noise (Table 1).

The series of 17 years is splitted into 3 periods presenting 3 stock situations; from 1995 to 1997 presented an over-fishing state then from 1998 to 2005 the stock pass by an under-fishing situation to be from 2006 to 2011 fully fished (Figure 5).

The maximum sustainable yield and the effort corresponding was presented in Table 2 with the lower and the upper limit by $95 \%$. The mean between the 2 models used show that the yield for the next year can't exceed $144,014 \mathrm{Kg}$ corresponding to a fishing effort of 187,563 trips.

\subsection{Incorporation of Climate Parameter Using Classical Approach of Surplus Production Models}

The landings are quite variable at both monthly and yearly scales (Figure 6). The Melicertus kerathurus is fished around the year particularly during the spring, the summer and the autumn (Figure 6) from the north to the east.

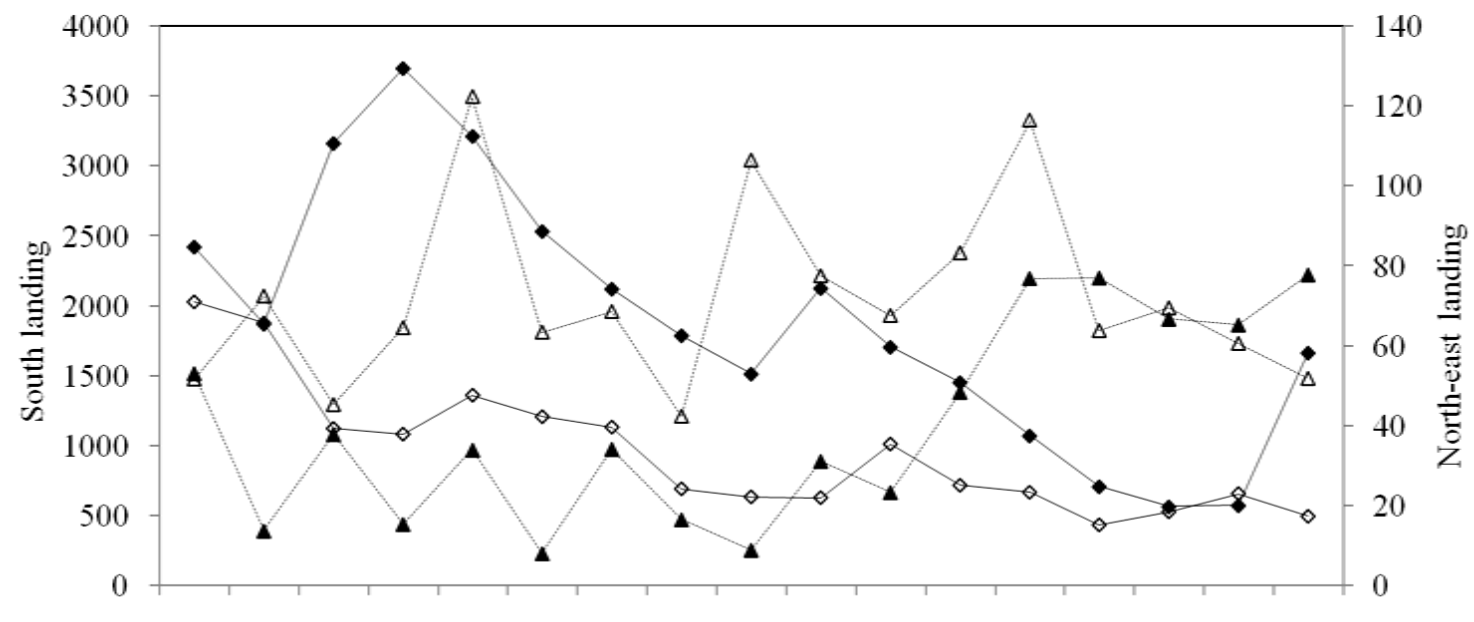

19951996199719981999200020012002200320042005200620072008200920102011

$\longrightarrow$ Trawl (South) — Artisanal (South) - $\_$Trawl (North-East) $\triangle$ Artisanal (North-East)

Figure 4. Melicertus kerathurus landing caught by industrial and artisanal fisheries.

Table 1. Parameters of global model resulted from CLIMPROD software.

\begin{tabular}{ccccccc}
\hline Parameters & Model & $\mathrm{A}$ & $\mathrm{b}$ & Determination coefficient $\mathrm{R}^{2}$ & ${\text { Jackknife } \mathrm{R}^{2}}^{\text {Test of Jackknife }}$ \\
\hline Schaefer model & $\mathrm{CPUE}=\mathrm{a}+\mathrm{b} * \mathrm{E}$ & 1.65593 & -0.000005 & 0.45 & 0.32 & Good \\
Fox model & $\mathrm{CPUE}=\mathrm{aexp}^{(\mathrm{b} \text { E })}$ & 1.955182 & -0.000005 & 0.43 & 0.25 & Good \\
\hline
\end{tabular}

Table 2. Maximum sustainable yield and the effort corresponding with the lower and the upper limit by 95 \% (MSE: maximum sustainable effort; MSY: maximum sustainable yield).

\begin{tabular}{ccccccc}
\hline Target point & MSE lower limit 95\% & MSE & MSE upper limit 95\% & MSY lower limit 95\% & MSY & MSY upper limit 95\% \\
\hline Schaefer model & $164,040.52$ & $177,068.99$ & $190,097.45$ & $139,684.01$ & $146,301.1$ & $152,918.2$ \\
Fox model & $155,982.3$ & $198,056.32$ & $24,0130.34$ & $127,679.99$ & $141,726.12$ & $155,772.26$ \\
\hline
\end{tabular}




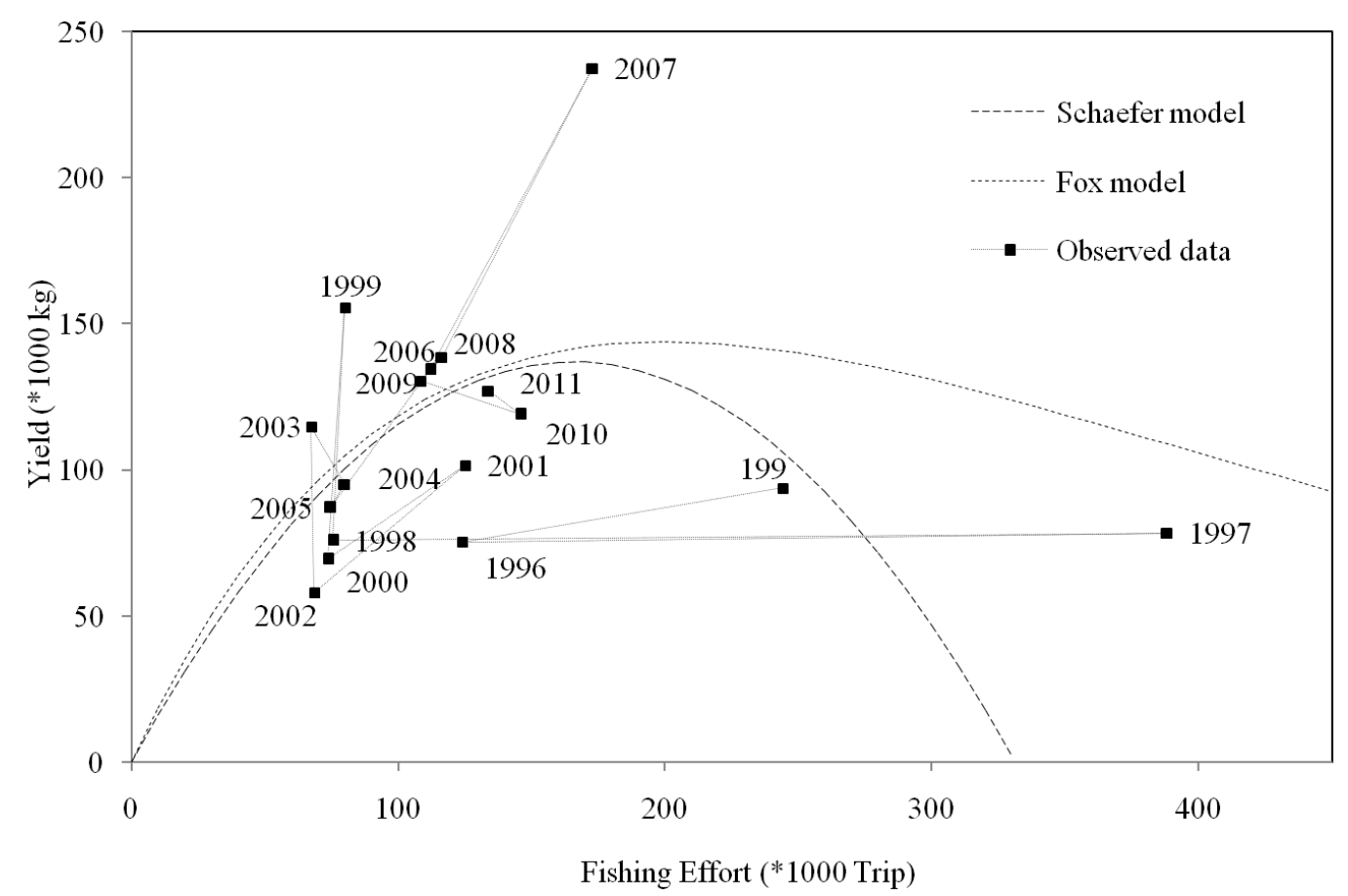

Figure 5. Schaefer and fox model illustrated for Melicertus kerathurus fisheries in the north-east of tunisia.

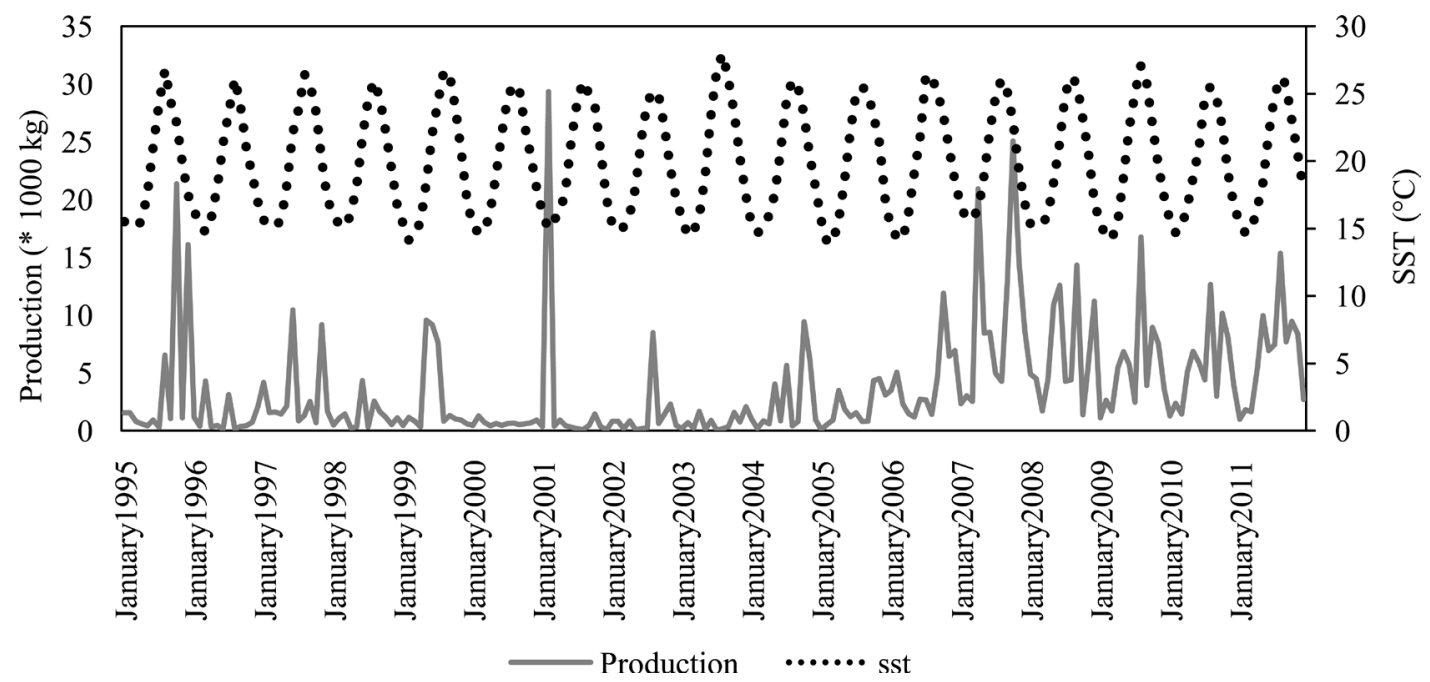

Figure 6. Monthly fluctuations of landing and SST from January 1995 to December 2011.

SST fluctuated within an obvious seasonal cycle, with a maximum in August $\left(26.2^{\circ} \mathrm{C}\right)$ and a minimum in February $\left(14.8^{\circ} \mathrm{C}\right)$ (Figure 6). Year-to-year variations can be seen in the monthly extremes and in the annual averages, which range from $19.4^{\circ} \mathrm{C}$ to $20.4^{\circ} \mathrm{C}$ (Figure 6).

The cross-correlation between the Melicertus kerathurus landing and the SST is showed in Figure 7. Lagged correlations of monthly values of landing and SST are small, yet show consistent patterns for each variable (Figure 7). In fact, for landing, correlation with SST clearly peaks with positive values between lags of [0; 2]; [6; 7] and $[11 ; 12]$ months and negative values elsewhere.

The incorporation of climatic variable in global model using CLIMPROD presented that there is a significant and stronger year-to-year correlation between CPUE and the landing and the effort even for both the hot and the cold season, while, the correlation between CPUE and the SST is depending to the season, the correlation is significant during the hot but none of the cold one (Table 3). 


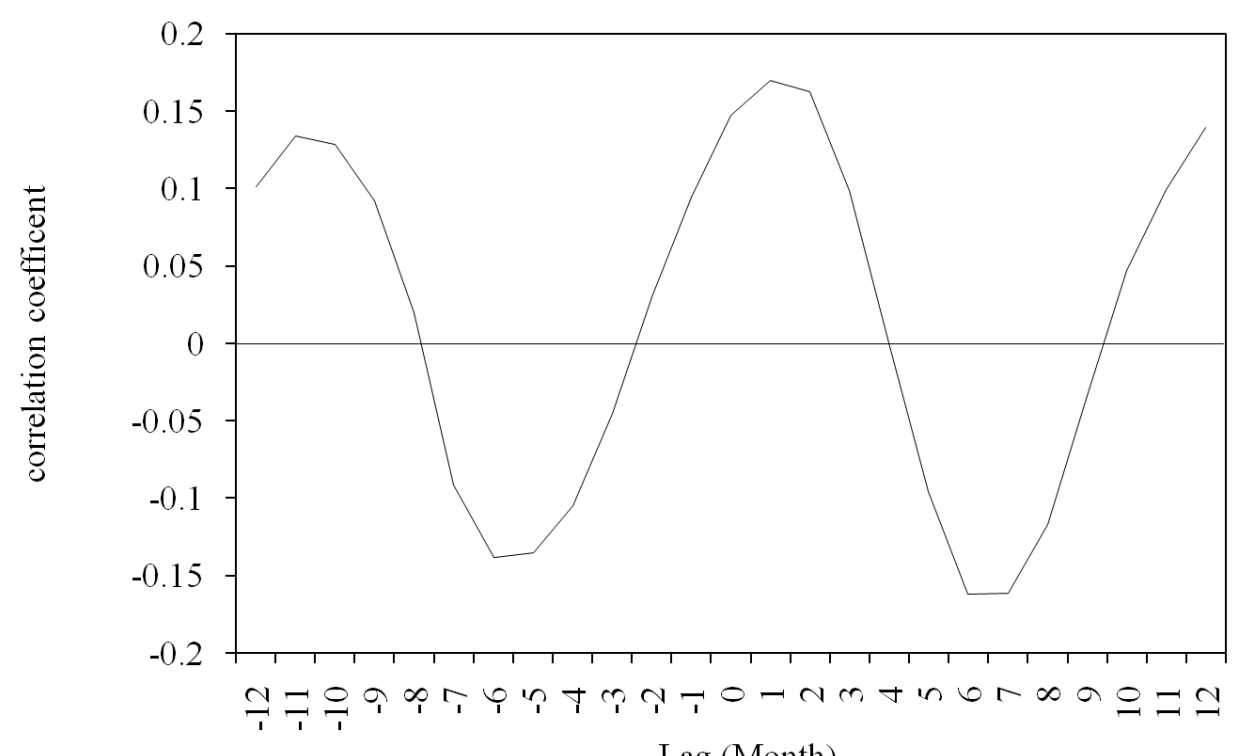

Lag (Month)

Figure 7. Lagged correlation coefficient between landing and SST.

Table 3. CLIMPROD results about correlation (R) between landing, CPUE, fishing effort and the SST during hot season.

\begin{tabular}{|c|c|c|c|c|c|}
\hline \multicolumn{2}{|c|}{ Correlation coefficient (R) } & Landing & CPUE & Effort & SST \\
\hline \multirow{4}{*}{ Hot season } & Landing & 1.000 & & & \\
\hline & CPUE & $0.540^{*}$ & 1.000 & & \\
\hline & Effort & 0.026 & $-0.661^{*}$ & 1.000 & \\
\hline & SST & 0.465 & $0.570^{*}$ & -0.189 & 1.000 \\
\hline \multirow{4}{*}{ Cold season } & Landing & 1.000 & & & \\
\hline & CPUE & $0.540^{*}$ & 1.000 & & \\
\hline & Effort & 0.026 & $-0.661^{*}$ & 1.000 & \\
\hline & SST & 0.418 & 0.426 & 0.073 & 1.000 \\
\hline
\end{tabular}

*Significant correlation.

CLIMPROD presented the impact of the SST and the fishing effort on the catchability and the abundance of the Melicertus kerathurus during the hot season, which it's corresponding to the recruitment and spawning period (Table 4). Taking into account the environmental influence caused by the SST and the fishing effort on the production, the models chosen (Table 4) demonstrated a clear difference on the results compared to the global model without the incorporation of a climate parameter confirming the significant contribution of the combination of the effort and environmental parameter to study the double effect of the SST on CPUE affecting the catchabilty by $54 \%$ and the abundance by $58 \%$ (Table 4 ).

The variability of the species abundance is influence by the SST. The model chosen present different situation which depend on the water temperature. For SST $=21.3^{\circ} \mathrm{C}$ the stock is under-fished all the year except for 1995 and 1997 but for SST $=20^{\circ} \mathrm{C}$ the stock is considered over-fished from 1995 to 1997, under-fished from 1998 to 2005 and fully fished from 2006 to 2011. For the catchability, SST is playing also a role, in fact, when SST = $20^{\circ} \mathrm{C}$, the stock is considered fully and under-fished whereas when the SST $=21.3^{\circ} \mathrm{C}$ the stock is fully even over-fished (Figure 8).

According to the impact on the catchability and the abundance, Table 5 gives the maximum sustainable yield and the effort corresponding with the lower and the upper limit by 95\% depending on the SST.

\section{Discussions}

Melicerthus kerathurus is a demersal species widely distributed in the Atlantic and Mediterranean Sea [4] [5]. 
Table 4. Models and parameters of global model resulted from the introduction of SST in the surplus production models.

\begin{tabular}{cccccccc}
\hline Impact & Model & a & $\mathrm{b}$ & $\mathrm{c}$ & $\begin{array}{c}\text { Determination } \\
\text { coefficient } \mathrm{R}^{2}\end{array}$ & $\begin{array}{c}\text { Jackknife } \\
\mathrm{R}^{2}\end{array}$ & $\begin{array}{c}\text { Test of } \\
\text { Jackknife }\end{array}$ \\
\hline Catchability & $\mathrm{CPUE}=\mathrm{a}+\mathrm{b} * \mathrm{~V}-\mathrm{c} *(\mathrm{a}+\mathrm{b} * \mathrm{~V})^{2} * \mathrm{E}$ & -10.248 & 0.582 & $0.002 \times 10^{-3}$ & 0.54 & 0.32 & Good \\
Abondances & $\mathrm{CPUE}=\mathrm{a}+\mathrm{b} * \mathrm{~V}+\mathrm{c} * \mathrm{E}$ & -14.4923 & 0.787 & $-0.004 \times 10^{-3}$ & 0.58 & 0.42 & Good \\
\hline
\end{tabular}

Table 5. Maximum sustainable yield and the effort corresponding with the lower and the upper limit by 95\% (MSE: maximum sustainable effort; MSY: maximum sustainable yield) taking into account the SST effect on the global models.

\begin{tabular}{|c|c|c|c|c|c|c|c|}
\hline & $\begin{array}{l}\text { Remarquables } \\
\text { values }\end{array}$ & $\begin{array}{l}\text { MSE lower limit } \\
95 \%\end{array}$ & MSE & $\begin{array}{l}\text { MSE upper limit } \\
95 \%\end{array}$ & $\begin{array}{c}\text { MSY lower limit } \\
95 \%\end{array}$ & MSY & $\begin{array}{c}\text { MSY upper limit } \\
95 \%\end{array}$ \\
\hline \multirow{4}{*}{ Catchability } & Mean: 20.37 & $133,754.28$ & $189,245.54$ & $244,736.8$ & $123,258.42$ & $150,854.67$ & $178,450.91$ \\
\hline & Median: 20.30 & $136,051.22$ & $194,289.74$ & $252,528.26$ & $123,258.42$ & $150,854.67$ & $178,450.91$ \\
\hline & Minimum: 20.00 & $146,390.92$ & $219,940.13$ & $293,489.33$ & $123,258.42$ & $150,854.67$ & $178,450.91$ \\
\hline & Maximum: 21.30 & $107,174.68$ & $140,170.57$ & $173,166.45$ & $123,258.42$ & $150,854.67$ & $178,450.91$ \\
\hline \multirow{4}{*}{ Abundance } & Mean: 20.37 & $183,111.19$ & $211,664.93$ & $240,218.67$ & $151,595.78$ & $161,766.59$ & $171,937.39$ \\
\hline & Median: 20.30 & $178,677.52$ & $204,101.96$ & $229,526.40$ & $143,403.46$ & $150,470.09$ & $157,536.73$ \\
\hline & Minimum: 20.00 & $157,855.86$ & $171,099.90$ & $184,343.95$ & $95,684.54$ & $106,072.39$ & $116,460.23$ \\
\hline & Maximum: 21.30 & $241,011.44$ & $314,108.81$ & $387,206.18$ & $264,440.31$ & $355,998.4$ & $447,556.49$ \\
\hline
\end{tabular}

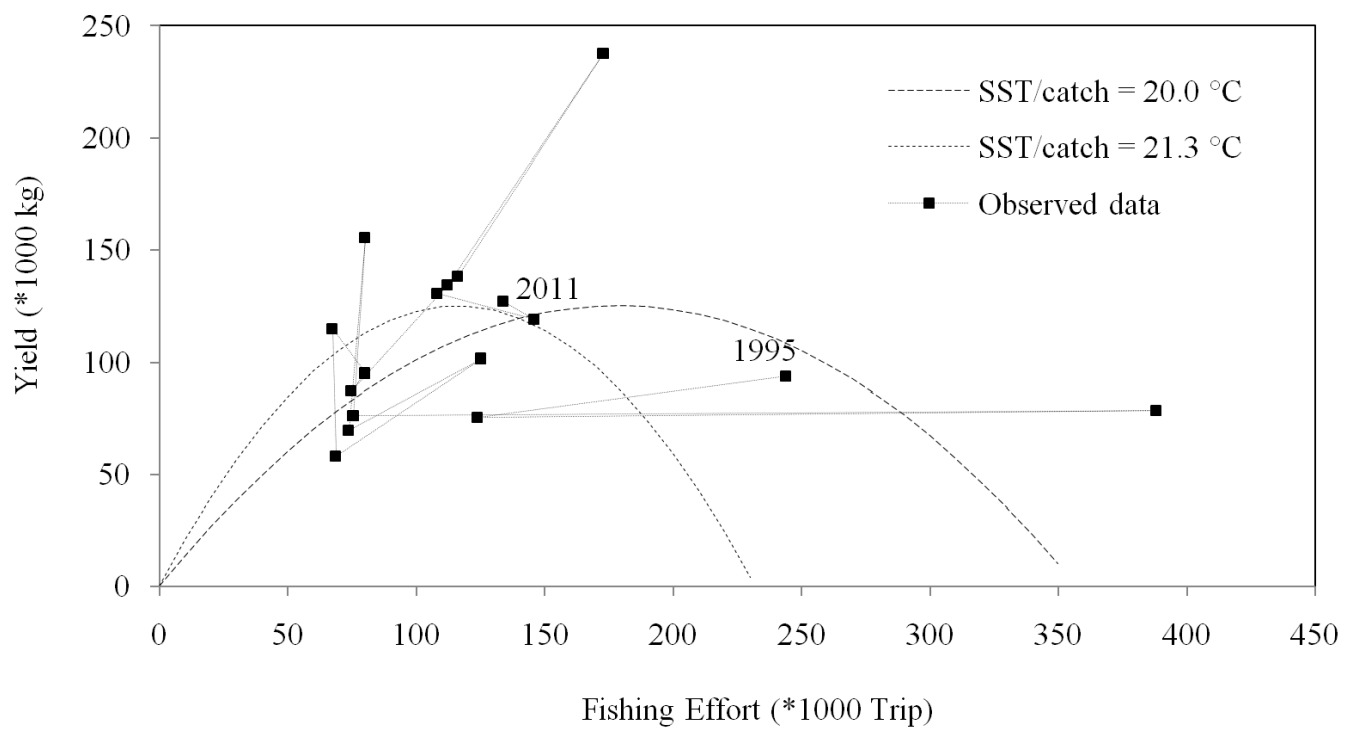

Figure 8. Melicertus kerathurus fishing effort and production in relation with SST during the hot season influencing the catchability. Parables are CLIMPROD model outputs for minimum and maximum values of SST. Dark squares are data points of the observed data.

This species lives on continental shelves in marine and brackish water at moderate depths from 5 to $90 \mathrm{~m}$ and mainly at a depth of $40 \mathrm{~m}$ on sandy and sandy-muddy bottom and it hides in pits of detritus [35]. This species is known as a littoral animal [12] [11] and its abundance decreases with the depth [36]. This species like shrimps is more active at night and spends much of the day buried in sediment [11] as a behavioral response to low temperature [37]. Like most Penaeus spp., after spawning in the pits of the offshore areas [10], post larvae invade shallow coastal areas are rich in food. Afterwards juveniles migrate to the offshore in autumn and winter to avoid extreme cold temperature [38] waiting for the spring and summer to return to the spawning areas [39]. 
This species is known as among the most important commercial species in the Mediterranean sea and especially in Tunisia, mainly in the south (from Ras Kabboudia to Libyan and Tunisian limit) but also in the northeastern coast of the country (from Algerian and Tunisian limit to Ras Kabboudia). According to [25] genetic variability along the Tunisian coast was low and the significant population differentiation was located between the two farthest points in the north (Tabarka) and the south (Djeba). Genetically, the Melicerthus kerathurus population can be divided into two stocks; however, there is no direct evidence to consider the intermediate region (from Kalâtlandalos to Gabes) as a putative contact zone between the two divergent entities [25]. For this reason, to delimit the two stocks, fisheries analysis was presented, showing that the Melicerthus kerathurus exploitation was different from zone to zone; we noted that the south stock was targeted mainly by the trawl fleet and the north-eastern one was caught especially by artisan fleet.

Global models presented $43 \%$ and $45 \%$ of the fluctuation of production due only to the effort and the rest was due to white noise. For our case, we associated the white noise to environmental parameters to try to find a relationship between fishing activity and life condition of Melicertus kerathurus. In the frame of stock management, this species will be dealt in the north-eastern cost separately from the south stock for an ultimate stock assessment for a good management of this species to explain the inter and intra-annual variability of Melicertus kerathurus landing.

As the most crustacean it is known to be a short-lived species, and like cephalopod, these families are known to be highly variable and influenced by environmental conditions [2] [40]-[42]. A lot of studies analyzed such combination between abundance and environmental parameters for crustacean family in the world [41] [43]-[45] [71] even in the Mediterranean Sea [46]-[52]; however, the analysis of relationship between climatic parameters and abundance of Melicertus kerathurus was scare [53] [54]. The most important abiotic parameter used to measure climate change is the sea surface temperature [55] which is an important indicator of the state of the earth's climate system [28]. According to [56] the water temperature can directly and indirectly affect marine poikilotherm populations. And with a variable growth rate and a short life span ( 24 months) for Melicertus kerathurus, [57] and [58] suggest a considerable impact of water temperature on the stock size. This is confirmed also for the Melicertus kerathurus aquaculture. A considerable literature was dealing with the manipulation of temperature and photoperiod, and showing the important role of these parameters; they played in gonadal maturation and spawning [59]-[62]. For several species also, the SST was a critical parameter during spawning, hatching success and timing, larval mortality, growth, recruitment and distribution [58] [63]-[65]; we cited for example the SST effect on Octopus vulgaris in the eastern Tunisian coast [42]; besides to positive SST impact, the negative one could be considered which was the case of deeper decapods crustacean because in the Mediterranean Sea, the water temperature remained constant along the entire slope [46].

In this paper, we presented for the first time, the relationship between environmental conditions and Melicertus kerathurus catches in the north-eastern coast of Tunisia, suggesting an environmental influences on Melicertus kerathurus catchability and abundance.

In fact, the relationship between catches and SST was without time-lags and the effect of environmental influence was considerable during the hot season controversy to the cold one. The association of hydrographic parameters and fishing presents the utility of this method in stock assessment compared to the classic approach of production model without the incorporation of climatic parameters.

The introduction of these parameters in the case of Melicertus kerathurus stock presented an impact on the abundance and the catchability of the species, which was the same case generally for the penaeid shrimp in southeastern United states [66], also for pink shrimp in Cuba (Gonazález-Yañez and Ortiz-Bultó, 2002) [67], for brown shrimp in the Gulf of Mexico [68] and for blue shrimp in the Gulf of California [69].

In Tunisian coast, during the hot season which coincided with recruitment period and the spawning period, the SST influenced positively the abundance when the catchability was constant; this could be explained by the important arrival of new recruits during the spring. In spite of that, the SST affected the catchability negatively. In fact, the catchability is defined as the proportion of a fish population caught by one unit of fishing effort and it depends on the accessibility (presence of the animal in fishing area) and the vulnerability (interaction between the gear and the animal) [69]. Knowing that warmer temperatures allow reproduction over a longer period [70], so the species goes to the bottom for spawning and the animals become non vulnerable to the trammel net although their presence in fishing area. Therefore the catchability decreases with the increase of SST.

Overall, and according to the result founded in this paper we have a contrasting effect of SST on abundance and catchability. We recommend during hot temperature to not increase the fishing effort in order to fish more 
crustacean. In contrary when the water temperature is low, it's recommended to increase the fishing effort for a yielded year. To know which SST recorded we increase or decrease the fishing effort, Figure 9 gives an idea about the SST average during the hot season even in the summer and the spring months. CLIMPROD chose some references points of SST (minimum, median, mean and maximum) to compare MSY and MSE for each SST (Table 5). At $21.3^{\circ} \mathrm{C}$, that corresponds to $26.04^{\circ} \mathrm{C}$ in summer and $17.02^{\circ} \mathrm{C}$ in spring; we should not increase the fishing effort. However, at $20^{\circ} \mathrm{C}$, fishing activity should be increased; this is corresponding to $23.7^{\circ} \mathrm{C}$ during summer and $16.09^{\circ} \mathrm{C}$ during spring (Figure 10).

Today, the understanding of the relationship and the interaction between the environmental parameter and the fishing activity is more realistic to the stock assessment and to the fishery management purposes to guarantee sustainable exploitation of crustacean resources over time.

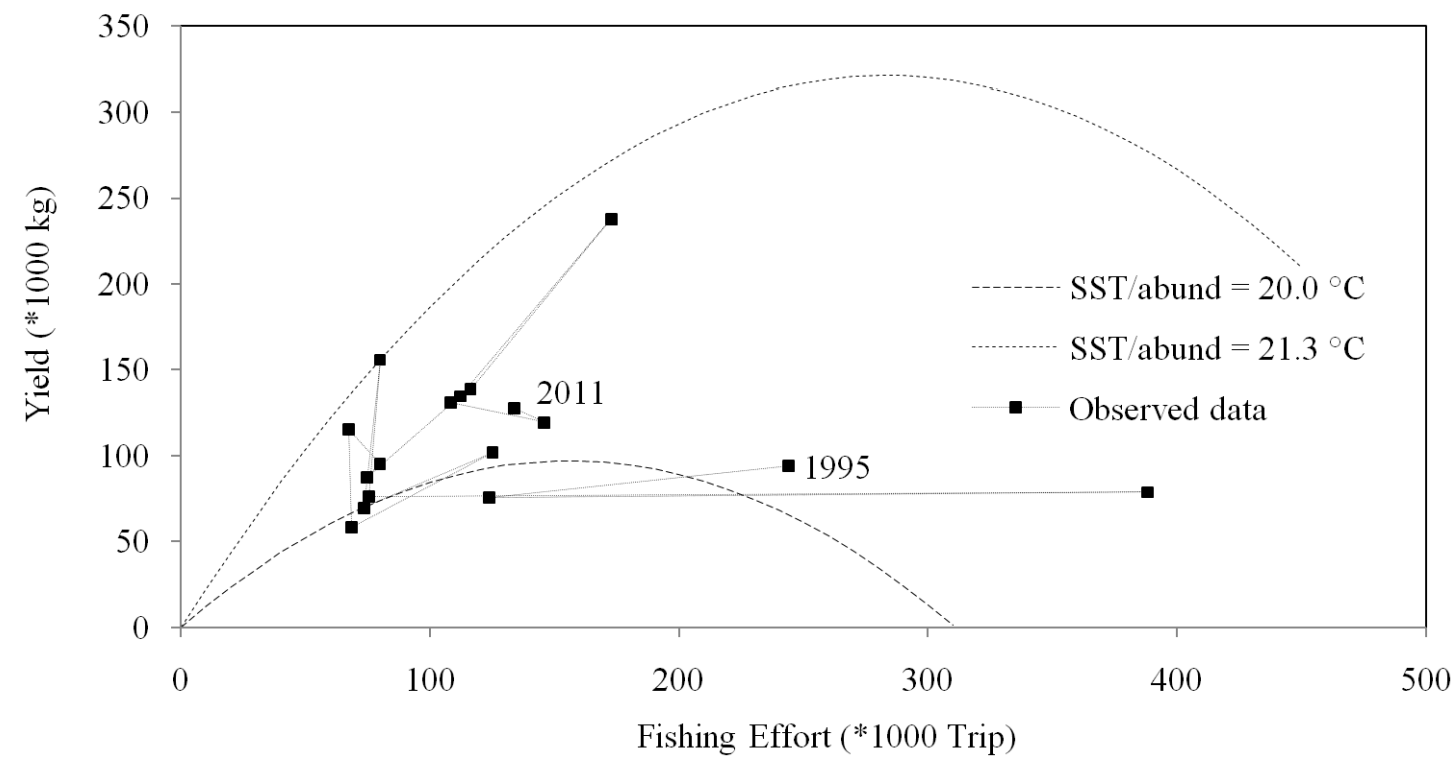

Figure 9. Melicertus kerathurus fishing effort and production in relation with SST during the hot season influencing the abundance. Parables are CLIMPROD model outputs for minimum and maximum values of SST. Dark squares are data points of the observed data.

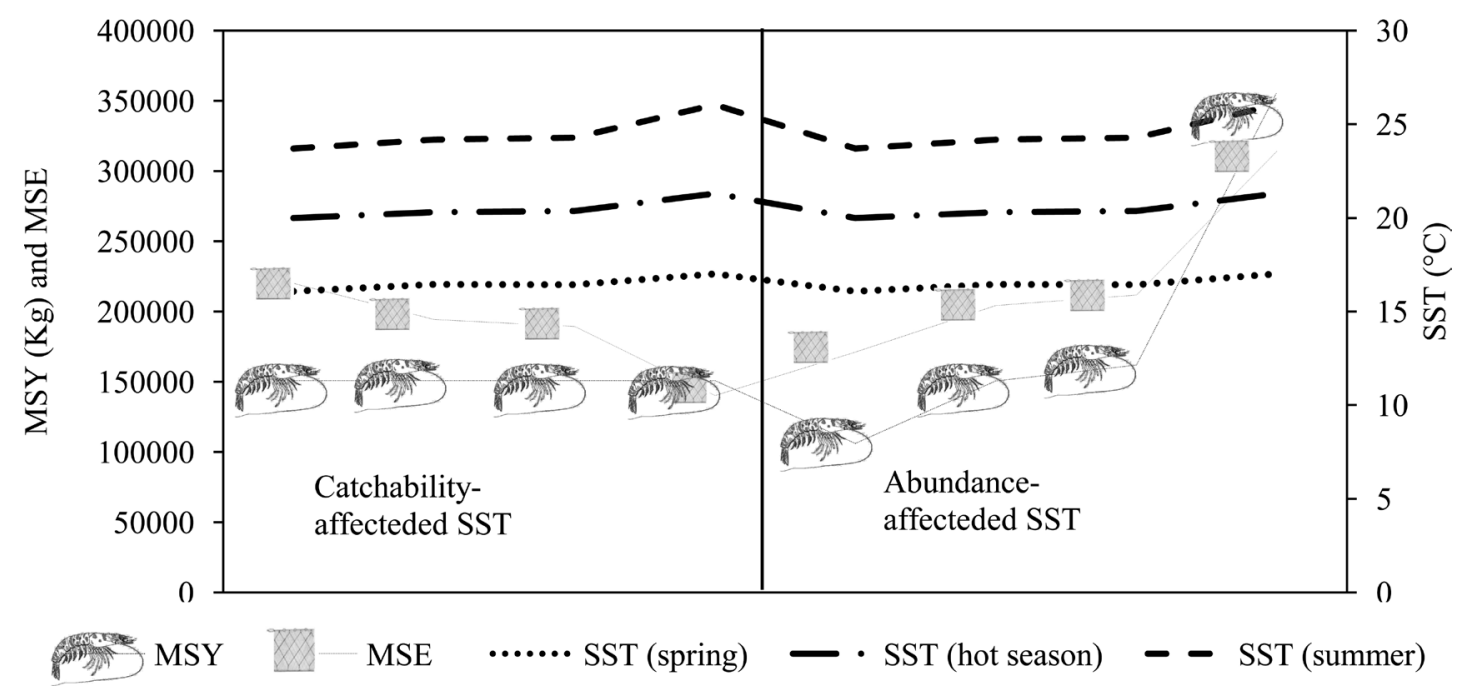

Figure 10. Melicertus kerathurus MSY and MSE for the minimum, median, mean and maximum SST during the hot season and their corresponding during the summer and the spring for the abundance-impacted SST and the catchability-impacted SST. MSY: maximum sustainable yield; MSE: maximum sustainable effort. 


\section{Acknowledgements}

Our thanks go to the DGPA; General Direction of Fishing and Aquaculture in Tunisia and to the NOAA; National Oceanic and Atmospheric Administration for their collaboration to make the fishing and climatic data available and facilitate our work.

\section{References}

[1] Punt, A.E., Huang, T. and Maunder, M.N. (2013) Review of Integrated Size-Structured Models for Stock Assessment of Hard-to-Age Crustacean and Mollusc Species. ICES Journal of Marine Science, 70, 16-33. http://dx.doi.org/10.1093/icesjms/fss185

[2] Santamarıá-del-Ángel, E., Millán-Núñez, R., González-Silvera, A., Callejas-Jiménez, M., Cajal-Medrano, R. and Galindo-Bect, M.S. (2011) The Response of Shrimp Fisheries to Climate Variability off Baja California, México. ICES Journal of Marine Science, 68, 766-772. http://dx.doi.org/10.1093/icesjms/fsq186

[3] Statistics and Information Service of the Fisheries and Aquaculture Department/Service des Statistiques et de l'Information du Département des pêches et de l'Aquaculture/Servicio de Estadísticas y Información del Departamento de Pesca y Acuicultura (2010) 2012 FAO Year Book. Fishery and Aquaculture Statistics. 2010/FAO Annuaire. Statistiques des pêches et de l’Aquaculture. 2010/FAO Anuario. Estadísticas de Pesca y Acuicultura. FAO, Rome/Roma, 78 p.

[4] Holthuis, L.B. (1980) FAO Species Catalogue: Shrimps and Prawns of the World. An Annotated Catalogue of Species of Interest to Fisheries. FAO Fisheries Synopsis, 1, 271 p.

[5] Dore, I. and Frimodt, C. (1987) An Illustrated Guide to Shrimp of the World. Osprey Books Huntington, New York, 229 p.

[6] Chaouachi, B. and Ben Hassine, O.K. (1998) Données sur la pêche des crevettes profondes Parapenaeus Iongirostris (Lucas, 1846) en Tunisie. In: Lleonart, J., Ed., Dynamique des Populations Marines, Cahiers Options Méditerranéennes Zaragoza, CIHEAM, 35, 201-213.

[7] Argüeso, L.I. (2012) Analysis of an International Fishery Company: Introduction to a Fishery Management Strategy Compatible with the Fishing Sector. Thesis (Master), Facultad de Ciencias del Mar, de Las Palmas de Gran Canaria, 47 p.

[8] Heldt, J.H. (1932) Sur quelques différences sexuelles (Coloration, Taille, Rostre) chez deux crevettes tunisiennes: Caramote Panaeus Risso et Parapenaeus longirostris Lucas. Bulletin de Station Océanographique de Salammbô, 27, 125.

[9] Heldt, J.H. (1938) La reproduction chez les Crustacés Décapodes de la famille des Pénéides. Annales de l'Institut. Océanographique de Paris, 28, 1-206.

[10] Heldt, J.H. (1954) Contribution à l'étude de la biologie des Pénéides. Bulletin de la Station Océanographique de Salammbô, 47, 5-27.

[11] Ben Mustapha, A. (1967) Observations biologiques sur Melicerthus kerathurus Forskal et étude biométrique. Annales Bulletin de l'Institut National Scientifique et Technique d'Océanographie et de Pêche de Salammbô, XIII.

[12] Azouz, A. (1972) Les crustacés comestibles (crevettes et langoustines) des mers tunisiennes. Bulletin de l'Institut National Scientifique et Technique d'Océanographie et de Pêche de Salammbô, 2, 275-301.

[13] Ben Khemis, L. and Ghorbel, M. (1979) Campagne de prospection des zones à crevettes dans le golfe de Gabès (12-27 septembre 1979). Rapport Document. Bulletin de l'Institut National Scientifique et Technique d'Océanographie et de Pêche de Salammbô, 4-79, 3-20.

[14] Ben Khemis, L. and Ghorbel, M. (1981) Rapport sur la campagne de prospection du "Hannoun” dans la région Sud (Zones à crevettes du golfe de Gabès) 27-29 mars 1981. Bulletin de l'Institut National Scientifique et Technique d'Océanographie et de Pêche de Salammbô, 2-81, 15-23.

[15] Ghorbel, M. and Ben Khemis, L. (1980) Mission du "Hannoun” dans le golfe de Gabès (Zones à crevettes) du 7 au 26 mai 1980. Rapport Document. Bulletin de l'Institut National Scientifique et Technique d'Océanographie et de Pêche de Salammbô, 3, 5-31.

[16] Ben Khemis, L. (1981) La pêche de la crevette caramote dans le golfe de Gabès: Quelques observations sur l'évolution de la production et de l'état d'exploitation. Rapport Document. Bulletin de l'Institut National Scientifique et Technique d'Océanographie et de Pêche de Salammbô, 3-81, 2-18.

[17] Ben Khemis, L., Zaarah, Y. and Ben Salah, K. (1982) Rapport sur les campagnes de prospection du "Hannoun” dans le golfe de Gabès (Zones à crevettes) 10-27 juin et 11-26 août 1982. Rapport Document. Bulletin de l'Institut National Scientifique et Technique d'Océanographie et de Pêche de Salammbô, 3-82, 3-12.

[18] Ben Meriem, S. (1993) Taille de première maturité sexuelle et période de ponte de Penaeus kerathurus du golfe de 
Gabès (Decapoda, Penaeoidea). Crustaceana, 65, 82-96. http://dx.doi.org/10.1163/156854093X00405

[19] Ben Meriem, S. (1995) Caractères biométriques de Penaeus kerathurus du golfe de Gabès (Decapoda, Penaeoidea). Crustaceana, 68, 583-596. http://dx.doi.org/10.1163/156854095X01763

[20] Ben Meriem, S. (1998) Mortalités (F et M) et analyse des rendements par recrue de Penaeus kerathurus (Forskal) du golfe de Gabès, Tunisie. Cahiers Option Méditerranéenne, 35, 25-34.

[21] Anonyme (2002) Projet national de recherche de l'INSTM: Evaluation des Ressources Halieutiques Tunisiennes (1996-2002). Rapport Final: Espèces demersales, espèces pélagiques et indicateurs socio-économiques, Vol. 2, 246 p.

[22] M'rabet, R. (2003) La mise au point des engins de pêche sélectifs est une contribution à une gestion rationnelle et durable des pêcheries en Tunisie. Communication. Forum international sur la pêche en Méditerranée Occidentale, Madrid (Espagne) du 23 au 25 juillet 2003.

[23] Bdioui, M. (2004) Sélectivité des filets trémails à crevettes dans le golfe de Gabès. Mastère, Institut National Agronomique de Tunis, Tunisie, $128 \mathrm{p}$.

[24] Bdioui, M., M’rabet, R., Ben Naceur, L., Missaoui, H. and Ben Salem, S. (2004) Aspects techniques d'exploitation du métier trémails à crevettes dans le golfe de Gabès. Bulletin de l'Institut National Scientifique et Technique d'Océanographie et de Pêche de Salammbô, 31, 53-60.

[25] Zitari-Chatti, R., Chatti, N., Elouaer, A. and Said, K. (2008) Genetic Variation and Population Structure of the Caramote Prawn Penaeus kerathurus (Forskäl) from the Eastern and Western Mediterranean Coasts in Tunisia. Aquaculture Research, 39, 70-76. http://dx.doi.org/10.1111/j.1365-2109.2007.01874.x

[26] Jaziri, H. and Ben Meriem, S. (2011) Changement spatio-bathymétrique de la taille de la crevette, Penaeus kerathurus (Forskal, 1775) par sexe et localisation en Tunisie. $13^{\text {eme }}$ Journée des Sciences Marine Tunisie et deuxième rencontre franco-tunisienne d’Ichtyologie 26-29 Novembre 2011. Communication par poster, Mahdia, Unpublished.

[27] Mili, S., Bouriga, N., Ennouri, R. and Missaoui, H. (2014) Positionnement phylogénétique des crevettes royales Melicertus Penaeus kerathurus (Forskâl, 1775) des eaux tunisiennes. Poster. Journée Scientifique de l'INAT, 2014. Changements climatiques et mesures d'adaptations. Unpublished.

[28] Reynolds, R.W., Rayner, N.A., Smith, T.M., Stokes, D.C. and Wang, W. (2002) An Improved In Situ and Satellite SST Analysis for Climate. Journal of Climate, 15, 1609-1625. http://dx.doi.org/10.1175/1520-0442(2002)015<1609:AIISAS>2.0.CO;2

[29] Fréon, P., Mullon, C. and Pichon, G. (1993) Experimental Interactive Software for Choosing and Fitting Surplus Production Models Including Environmental Variables. FAO Computerized Information Series (Fisheries), Rome, No. 5, $76 \mathrm{p}$.

[30] Duncan, T. (1978) An Empirical Study of Jackknife-Consfructed Confidence Regions in Non Linear Regression. Technometrics, 20, 123-129. http://dx.doi.org/10.1080/00401706.1978.10489636

[31] Schaefer, M.B. (1954) Some Aspects of the Dynamics of Populations Important to the Management of Commercial Marine Fisheries. Inter-American Tropical Tuna Commission, 1, 26-56.

[32] Schaefer, M.B. (1957) A Study of the Dynamics of the Fishery for Yellowfin Tuna in the Eastern Tropical Pacific Ocean. Inter-American Tropical Tuna Commission, 2, 247-285.

[33] Fox, W.W. (1970) An Exponential Yield Model for Optimizing Exploited Fish Populations. Transactions of the American Fisheries Society, 99, 80-88. http://dx.doi.org/10.1577/1548-8659(1970)99<80:AESMFO>2.0.CO;2

[34] Pella, J.J. and Tomlinson, P.K. (1969) A Generalized Stock Production Model. Inter-American Tropical Tuna Commission Bulletin, 13, 419-496.

[35] Holthuis, L.B. (1987) Crevettes. In: Fischer, W., Bauchot, L. and Schneider, M., Eds., Fiches FAO d'identification des espèces pour les besoins de la pêche Méditerranée et mer Noire, Zone de pêche 37, Vol. 1, Végétaux et Invertébrés, Rome, 189-192.

[36] Gharbi, H. and Ben Meriem, S. (1996) Résultats de chalutages expérimentaux de Mai à Juin 1996 dans le golfe de Gabès. Bulletin Institut National des Sciences et Technology de la Mer, 23, 80-96.

[37] Aldrich, D.V., Wood, C.E. and Baxter, K.N. (1968) An Ecological Interpretation of Low Temperature Responses in Penaeus aztecus and P. setiferus Postlarvae. Bulletin of Marine Science, 18, 61-71.

[38] Britta, E.S., Geert, H.J. and Wim, J.W. (2006) Habitat Use of Shrimps in the Intertidal and Shallow Subtidal Seagrass Beds of the Tropical Banc d'Arguin, Mauritania. Journal of Sea Research, 55, 230-243. http://dx.doi.org/10.1016/j.seares.2005.10.003

[39] George, J.P. (1977) Prospection des lieux de pêche de la crevette Penaeus kerathurus et introduction d'une nouvelle technique de pêche pour ce crustacé en Tunisie (1973-1975). Bulletin de l'Institut National Scientifique et Technique d'Océanographie et de Pêche de Salammbô, 4, 263-306.

[40] Caverivière, A., Thiam, M. and Jouffre, D. (Eds.) (2002) Le poulpe commun Octopus vulgaris. Sénégal et côtes 
nord-ouest africaines. Colloques et séminaires. Editions IRD, Paris, 385 p.

[41] Thiaw, M., Gascuel, D., Jouffre, D. and Thiaw, O.T. (2009) A Surplus Production Model Including Environmental Effects: Application to the Senegalese White Shrimp Stocks. Progress in Oceanography, 83, 351-360. http://dx.doi.org/10.1016/j.pocean.2009.07.024

[42] Jabeur, C., KHoufi, W. and Bakhrouf, A. (2010) Role of the Sea Surface Temperature and Rainfall on the Stock and Fishery of the Common Octopus (Octopus vulgaris, Mollusca, Cephalopoda) in Tunisia. Marine Ecology an Evolutionary Perspective, 31, 431-438. http://dx.doi.org/10.1111/j.1439-0485.2009.00345.x

[43] Fréon, P. (1991) L’introduction d'une variable climatique dans les modèles globaux de production. In: Cury, P. and Roy, C., Eds., Pêcheries ouest-africaines, Variabilité, Instabilité et Changement, Orstom éditions, Paris, 395-424.

[44] Castilho, A.L., Pie, M.R., Fransozo, A, Pinheiro, A.P. and Costa, R.C. (2008) The Relationship between Environmental Variation and Species Abundance in Shrimp Community (Crustacea: Decapoda: Penaeoidea) in South-Eastern Brazil. Journal of the Marine Biological Association of the UK, 88, 119-123. http://dx.doi.org/10.1017/S0025315408000313

[45] Drexler, M. and Ainsworth, C.H. (2013) Generalized Additive Models Used to Predict Species Abundance in the Gulf of Mexico: An Ecosystem Modeling Tool. PLoS ONE, 8, e64458. http://dx.doi.org/10.1371/journal.pone.0064458

[46] Cartes, J.E. and Sardá, F. (1993) Zonation of Deep-Sea Decapods Fauna in the Catalan Sea (Western Mediterranean). Marine Ecology Progress Series, 94, 27-34. http://dx.doi.org/10.3354/meps094027

[47] Ungaro, N. and Gramolini, R. (2006) Possible Effect of Bottom Temperature on Distribution of Parapenaeus longirostris (Lucas, 1846) in the Southern Adriatic (Mediterranean Sea). Turkish Journal of Fisheries and Aquatic Sciences, 6, 109-116.

[48] Mutlu, E. and Ergev, M.B. (2008) Spatio-Temporal Distribution of Soft-Bottom Epibenthic Fauna on the Cilician Shelf (Turkey), Mediterranean Sea. Revista de Biologia Tropical, 56, 1919-1946.

[49] Mutlu, E., Çinar, M.E. and Ergev, M.B. (2010) Distribution of Soft Bottom Polychaetes of the Levantine Coast of Turkey, Eastern Mediterranean Sea. Journal of Marine Systems, 79, 23-35. http://dx.doi.org/10.1016/j.jmarsys.2009.06.003

[50] Mutlu, E. and Ergev, M.B. (2012) Distribution of Soft-Bottom Mollusks (Mollusca) in Mersin Bay (Eastern Mediterranean Sea). Turkish Journal of Zoology, 36, 430-446.

[51] Daoulatli, A., Antit, M., Azzouna, A. and García Raso, J.E. (2013) Seasonal and Diel Changes in the Structure of a Crustacean Decapod Assemblage Associated to a Shallow Cymodocea nodosa Meadow in Northern Tunisia (Mediterranean Sea). An Overview of Mediterranean Decapod Taxocoenoses. Mediterranean Marine Science, 15, 59-71.

[52] Mutlu, E. and Ergev, M.B. (2013) Depth-Related Gradient of Soft-Bottom Crustacean Distribution along the Cilician Shelf. Turkish Journal of Zoology, 37, 262-276.

[53] Kevrekidis, K. and Thessalou-Legaki, M. (2006) Catch Rates, Size Structure and Sex Ratio of Melicertus kerathurus (Decapoda: Penaeidae) from an Aegean Sea Trawl Fishery. Fisheries Research, 80, 270-279. http://dx.doi.org/10.1016/j.fishres.2006.04.001

[54] Cuesta, J.A., González-Ortegón, E., Rodríguez, A., Baldó, F., Vilas, C. and Drake, P. (2006) The Decapod Custacean Community of the Guadalquivir Estuary (SW Spain): Seasonal and Inter-Year Changes in Community Structure. Hydrobiologia, 557, 85-95. http://dx.doi.org/10.1007/s10750-005-1311-1

[55] Colebrook, J.M. and Taylor, A.H. (1979) Year-to-Year Changes in the Sea-Surface Temperature, North Atlantic and North Sea 1948-74. Deep-Sea Research, 26A, 825-850. http://dx.doi.org/10.1016/0198-0149(79)90017-7

[56] Robin, J.P. and Denis, V. (1999) Squid Stock Fluctuation and Water Temperature: Temporal Analysis of English Channel Lolignidae. Journal of Applied Ecology, 36, 101-110. http://dx.doi.org/10.1046/j.1365-2664.1999.00384.x

[57] Ben Khemis, L. (1984) Pêche à la crevette dans le golfe de Gabès. Rapport Document. Bulletin de l'Institut National Scientifique et Technique d'Océanographie et de Pêche de Salammbô, 2, 3-30.

[58] Caddy, J.F. (1983) The Cephalopods: Factors Relevant to Their Population Dynamics and to the Assessment and Management of Stocks. In: Caddy, J.F. Eds., Advances in Assessment of World Cephalopod Resources, FAO Fisheries Technical Paper No. 231, FAO, Rome, 416-452.

[59] Lumare, F. (1979) Reproduction of Penaeus kerathurus Using Eyestalk Ablation. Aquaculture, 19, $203-214$. http://dx.doi.org/10.1016/0044-8486(79)90012-7

[60] Primavera, J.H. (1985) A Review of Maturation and Reproduction in Closed Thelycum Penaeids. In: Taki, Y., Primavera, J.H. and Llobrera, J.A., Eds., Proceedings of the First International Conference on the Culture of Penaeid Prawns/Shrimps, Iloilo City, 4-7 December 1984, Aquaculture Department, Southeast Asian Fisheries Development Center, Iloilo City, 47-64.

[61] Cripe, G.M. (1994) Induction of Maturation and Spawning of Pink Shrimp, Penaeus duarorum by Changing Water 
Temperature, and Survival and Growth of Young. Aquaculture, 128, 255-260. http://dx.doi.org/10.1016/0044-8486(94)90314-X

[62] Aktas, M., Kumlu, M. and Eroldogan, O.T. (2003) Off-Season Maturation and Spawning of Penaeus semisulcatus by Eyestalk Ablation and/or Temperature; Photoperiod Regimes. Aquaculture, 228, 361-370. http://dx.doi.org/10.1016/S0044-8486(03)00314-4

[63] Bakun, A. (1996) Patterns in the Ocean: Ocean Processes and Marine Population Dynamics. University of California Sea Grant, in Cooperation with Centro de Investigaciones Biológicas del Noroeste, La Paz, 323 p.

[64] Boyle, P. and Rodhouse, P. (2005) Cephalopods: Ecology and Fisheries. Blackwell Science, Oxford. http://dx.doi.org/10.1002/9780470995310

[65] Pierce, G.J., Valavanis, V.D., Guerra, A., Jereb, P., Orsi-Relini, L., Bellido, J.M., Katara, I., Piatkowski, U., Pereira, J., Balguerias, E., Sobrino, I., Lefkaditou, E., Wang, J., Santurtun, M., Boyle, P.R., Hastie, L.C., MacLeod, C.D., Smith, J.M., Viana, M., González, A.F. and Zuur, A.F. (2008) A Review of Cephalopod Environment Interactions in European Seas. Hydrobiologia, 612, 49-70. http://dx.doi.org/10.1007/s10750-008-9489-7

[66] Witzell, W.N. and Allen, D.M. (1982) Summary of Studies Relating Coastal Climatological Factors and Commercial Shrimp Production, Southeastern United States. Western Central Atlantic Fishery Commission Working Party on Assessment of Marine Fishery Resources, Third Session, Kingston, 17-21 May 1982, FAO Fisheries Report No. 278, 111-119.

[67] Gonazález-Yañez, A.A. and Ortiz-Bultó, P. (2002) Seasonal Relationship between Climate and the Relative Abundance of Farfante penaeus notialis Pink Shrimp in the Gulf of Ana Maria, Cuba. Revista de Investigaciones Marinas, 23, 97-104.

[68] Li, J. and Clarke, A.J. (2005) Sea Surface Temperature and the Brown Shrimp (Farfante penaeus aztecus) Population on the Alabama, Mississippi, Louisiana and Texas Continental Shelves. Estuarine, Coastal and Shelf Science, 64, 261266. http://dx.doi.org/10.1016/j.ecss.2005.02.019

[69] Laurec, A. and Le Guen, J.E. (1981) Dynamique des populations marines exploitées. Tome 1: Concepts et modèles. Rapport. Centre Océanologique de Bretagne, No. 45, 117 p.

[70] Aragón-Noriega, E.A. (2007) Coupling the Reproductive Period of Blue Shrimp Litopenaeus stylirostris Stimpson, 1874 (Decapoda: Penaeidae) and Sea Surface Temperature in the Gulf of California. Revista de Biología Marina y Oceanografía, 42, 167-175. http://dx.doi.org/10.4067/S0718-19572007000200004

[71] Furlan, M., Castilho Antonio, L., Fernandes-Góes, L.C., Fransozo, V., Bertini, G. and Da Costa Rogério, C. (2013) Effect of Environmental Factors on the Abundance of Decapods Crustaceans from Soft Bottoms off Southeastern Brazil. Annals of the Brazilian Academy of Sciences, 85, 1345-1356. http://dx.doi.org/10.1590/0001-3765201394812 